\title{
Consumers' Journey between Liquid and Solid Consumption
}

\author{
Edoardo Beretta ${ }^{1, *(D)}$, Giulia Miniero ${ }^{2, *}$ and Francesco Ricotta $^{3}$ \\ 1 Institute of Economics, Università Della Svizzera Italiana, 6900 Lugano, Switzerland \\ 2 Business and Economics Division, Franklin University Switzerland, 6924 Lugano, Switzerland \\ 3 Dipartimento di Management, Università Degli Studi di Roma "La Sapienza", 00185 Rome, Italy; \\ francesco.ricotta@uniroma1.it \\ * Correspondence: edoardo.beretta@usi.ch (E.B.); gminiero@fus.edu (G.M.); \\ Tel.: +41-58-666-41-32 (E.B.); +41-91-985-22-78 (G.M.)
}

Citation: Beretta, E.; Miniero, G.; Ricotta, F. Consumers' Journey between Liquid and Solid Consumption. Sustainability 2021, 13, 13730. https://doi.org/10.3390/ su132413730

Academic Editor:

Manuela Tvaronaviciene

Received: 3 November 2021

Accepted: 7 December 2021

Published: 13 December 2021

Publisher's Note: MDPI stays neutral with regard to jurisdictional claims in published maps and institutional affiliations.

Copyright: (c) 2021 by the authors. Licensee MDPI, Basel, Switzerland. This article is an open access article distributed under the terms and conditions of the Creative Commons Attribution (CC BY) license (https:/ / creativecommons.org/licenses/by/ $4.0 /)$.

\begin{abstract}
Sharing economy brought changes both at the macroeconomic and the individual level. New models of consumption, such as the liquid one, are becoming very frequent, shaping countries' productive systems and consumers' habits. This paper-combining both theoretical approachesaims at measuring the individual characteristics that induce consumers to prefer liquid versus solid consumption. First, the article contextualizes the topic from a broader, macroeconomic perspective, and later on, it narrows its angle of view making it rather microeconomic and behavioral. In this specific regard, by means of a cluster analysis, four profiles of consumers are identified: (1) Rational and liquid; (2) Hybrid and question mark; (3) Solid in transition; (4) Hyper solid. Characteristics as well as theoretical and managerial implications are outlined for each cluster. This research focusing on emerging consumer behavior contributes to the current debate on solid and liquid consumption (i) exploring the continuum between these two extremes, (ii) defining a first behavioral profile of customer that are traveling between solid and liquid state and (iii) designing a possible way to target such a blurred and fast evolving customer that mostly qualifies a global and rapidly evolving economic environment.
\end{abstract}

Keywords: consumption; liquid; sharing economy; solid; sustainability

\section{Introduction}

Sharing economy is nowadays a particularly important facet of modern society. It is driven by digitalization that allows firms to interact with their customers on a daily basis by the need of reducing the environmental impact of both companies and individual actions and by the growing consciousness for environment that consumers are developing day by day.

At the individual level, the advent of sharing economy brings changes and different approaches on consumption habits and choices. In the modern society, often described as liquid [1,2], the rise of sharing economy drives consumption decisions that are based on the access model rather than on the ownership model. In this scenario, the concept of liquid versus solid consumption [3,4] emerges. Liquid consumption, grounded on an access-based model, is becoming a very frequent approach for consumers. Scholarly works have so far concentrated their attention on explaining the contextual determinants of this phenomenon, overlooking the individual and psychological characteristics at the individual level that might induce consumers to engage into a more solid versus liquid consumption approach. This work tries to contribute exactly to this research gap. By means of a cluster analysis on seven psychological characteristics, four different segments associated with different consumer behavior, grounded on the solid versus liquid continuum, are identified. Each of the customer profiles identified highlights specific characteristics of the individuals, providing a more detailed framework for assessing and interacting with consumers in the liquid society. The work is structured as follows: first, we propose a review concerning the 
most relevant trends for sharing economy under a macroeconomic perspective; second, a theoretical review of the liquid versus solid consumption approach is introduced. Then, the description of the methodology employed and the findings of the analysis are outlined. Finally, the discussion section illustrates the theoretical, managerial and policy implications of the work.

Moreover, the present study could be highly beneficial in augmenting the scientific knowledge of customers' preferences for shared goods, which is on the one hand an emerging trend in consumption patterns. Often associated with the concept of ownership, consumption has been explored adopting an exclusive approach thus excluding microto the benefit of a macroeconomic approach or vice versa. Our paper tries to adopt an inclusive methodological perspective combining a preliminary macroeconomic analysis with a subsequent, specifically microeconomic-behavioral research. Both entail innovative conclusions where the first (i.e., macroeconomic) part intends to create a logical continuum with the second (i.e., microeconomic) one-evidently, in the same way solid and liquid consumption are a continuum instead of representing two opposite ways of consuming goods and services.

\section{Macroeconomic Justifications of the Sharing Economy and the Antecedent of Liquid Consumption in a European Perspective}

In order to grasp the scientific relevance of our empirical findings, we contextualize consumption trends within an economically broader, macroeconomic perspective. If Gross Domestic Product (GDP) - namely, "the value added created through the production of goods and services in a country during a certain period "measuring" the income earned from that production, or the total amount spent on final goods and services (less imports)" [5] - remains despite providing nearly no information on non-economic wellbeing and nonvaluable activities [6,7], "the" economic measure par excellence, consumption represents another facet of production. In fact, "any act of production is a productionconsumption, a wave" [8]. Neither economies nor (even) trade would exist without production. Any newly created added value has the sole purpose of being spent, namely either consumed or invested. In this specific regard, even financial saving implies spending economic resources and buying securities. More interestingly, for the sake of the following analysis, any consumption, but also investment expenditure, implies that a share of production and its added value is "finally" spent. Final consumption expenditure is, therefore, tightly related to GDP where new economic needs, trends etc. affect it conversely. Monetarily speaking, "the final purchase of the product takes place by debiting the income holders and crediting the company. Since the income is identified with the product, this operation also constitutes an absolute exchange. However, while during the payment of wages money and product give life to income, after its final expenditure the product gets rid of its monetary essence to be once again turned into a simple set of physical objects" [own translation] [9]. While added value goes hand in hand with production, so does consumption with GDP.

Final consumption expenditure as compared to GDP must, therefore, represent the starting point of our introductory macroeconomic analysis. If we take the United Kingdom and the European Union for the sake of coherence with the following cluster analysis, the British final consumption expenditure has been particularly high in the Seventies and Eighties - respectively, at $86.7 \%$ and $86.4 \%$ of GDP on average-while it plummeted in the middle of the Nineties (1996) to $81.1 \%$. In more recent years (2015-2020), instead, it stabilized rather at $83-84 \%$ [10].

Moreover, as pointed out in Figure 1, final consumption expenditure in the European Union (27 countries) and in the world (195 countries) has been lower-respectively, at $75.8 \%$ and $81.1 \%$ of GDP on average [11] — than in the United Kingdom. In addition to the causal relation between final consumption expenditure and future production trends, indebtedness of private individuals also matters. For instance, we already know from the economic literature that "the decline in consumption following the Crisis was greater in areas that had higher outstanding loan-to-value ratios prior to the Crisis" [12]. Although 
final consumption expenditure is on average significantly lower than GDP-however, some small, often low-income countries like Liberia (130.9\%), Kiribati (150.7\%) or Somalia (172.6\%) have been even net borrowers between 2018 and 2020 to finance their excess purchases-link with macroeconomic variables affecting consumers such as the gross debt-to-income ratio of households is likely too. Moreover, "policy-makers and the mainstream economic literature largely neglect the role of private debt developments in causing financial crises and subsequent prolonged recessions" [13]. Although this is not the focus of our paper, macroeconomic interconnections also at the basis of sharing economy remain fundamental to be explored. Moreover, it should not be forgotten that according to [14], "throughout the industrialized world, more and more enterprises are focusing on their internal competences and operations, outsourcing all noncore competences to external suppliers or network partners". The well-known practice of outsourcing the production of goods and services is nothing else than a cost- and/or infrastructure-saving way of sharing. Servitization is, in fact, nowadays a major trend in the context of sustainability business models. Finally, another trend worth mentioning regards Product Service Systems (PSSs), which involve the development of "both tangible characteristics of the product and intangible ones related to the services surrounding the product, e.g., maintenance services and end-of-life recovery schemes, aiming to provide an integrated offering" [15]. As we will see, the sharing economy represents a multifaceted area of research and is characterized by several—both micro and macroeconomic — elements of interest affecting both the consumption as well as the production side of economic activities.

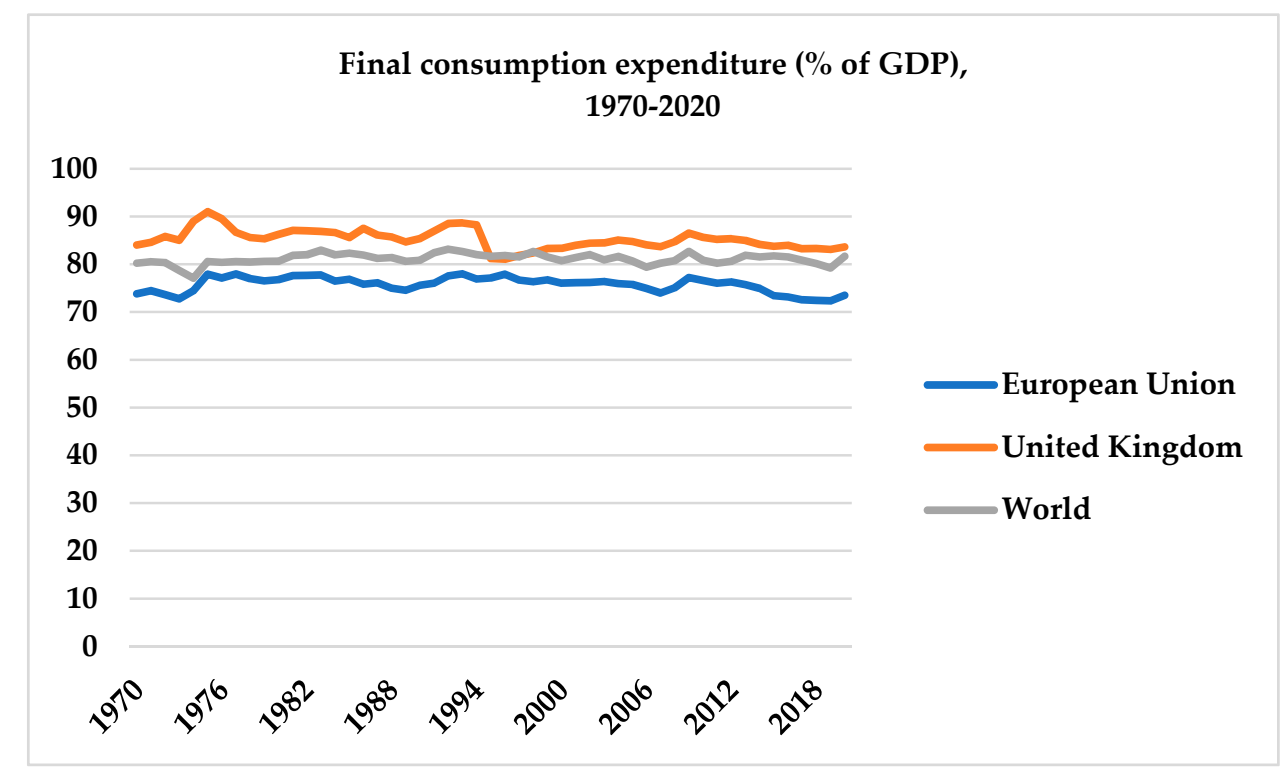

Figure 1. Final consumption expenditure (\% of GDP), 1970-2020 based on [11].

2.1. The Macroeconomic Nexus between Consumption, Economic Wellbeing of Consumers and the Sharing Economy

If we agree that final consumption expenditure and GDP influence each other, we are bound to conclude that (over-)indebtedness of the private sector, namely of the driving force of final consumption expenditure, affects consumer trends too. In fact, "negative longrun effects on consumption tend to intensify as the household debt-to-GDP ratio exceeds $60 \%$ " [16]. Moreover, the gross debt-to-income ratio of households might, macroeconomically speaking, "nudge" consumers to adapt consumption patterns to tighter financial boundaries. Within this context, the concept of sharing economy (or collaborative economy) itself is not new-in fact, "Marcus Felson and Joe L. Spaeth, in their study "Community Structure and Collaborative Consumption", introduced the term economy of sharing in 1978" [17], but the term has only recently gained relevance among the general public. 
Moreover, "given that the terms [sharing economy] and [collaborative consumption] are relatively new, a misunderstanding of their meaning prevails in the literature, as well as among consumers and service providers" [18], which is however a not necessarily to be introduced distinction. If the size of the sharing economy is plausibly influenced by factors like the local number of - and, even, accessibility to-companies supplying "shared" goods and services or the degree of openness to more sustainable consumption models [19], macroeconomic variables like the debt level of the private sector (and, especially, of households) represent a motivation to rearrange the local economy in the medium-long run so that consumer needs are still matched despite financial tightness. If economic resources are becoming limited, consumers might decide to adjust a part of their final consumption expenditure and share specific goods and services with other individuals instead of purchasing them. More generally, the worsening of the economic situation of consumers can be an incentive for the sharing economy as further confirmed by [20], who finds that "consumers are more strongly driven by economic motives, especially those who are more educated and trusting. Finally, providers with lower household income, who are more educated and innovative, are more likely to be driven by economic motives". In line with our preliminary conclusion, ref. [21] also find that "economic interests are holding back the purchase of people with a low level of education, a low standard of living, and a short-term budget planning period".

As highlighted in Table 1 listing the set of countries of the European continent for which the statistical items "individuals having used any website or app to arrange an accommodation from another individual", "individuals having used any website or app to arrange a transport service from another individual" and "gross debt-to-income ratio of households" have been compiled, there is the following statistical evidence:

(1) The gross debt-to-income ratio of households influences the average number of individuals having used websites/apps to arrange an accommodation or a transport service from another individual. By calculating the average number of consumers sharing an accommodation or a transport service-respectively, 18.8 (cf. accommodation) and 10.1 (cf. transport service) —we find that countries with individuals using websites/apps to arrange an accommodation or a transport service from another individual above the average have a higher gross debt-to-income ratio of householdsrespectively, 108.0 (cf. accommodation) and 105.4 (cf. transport service). Instead, countries with individuals using websites/apps to arrange an accommodation or a transport service from another individual below the average have a lower gross debt-to-income ratio of households-respectively, 87.8 (cf. accommodation) and 96.2 (cf. transport service). This result confirms our previous claim, according to which (over-)indebtedness of the private sector is an incentive to the sharing economy;

(2) The price dynamic within the specific economic sector-respectively, for accommodation and transport services-is less relevant than the gross debt-to-income ratio of households. While countries with individuals using websites/apps to arrange an accommodation or a transport service from another individual above the average have recorded lower increases of the Harmonized Indices of Consumer Prices (HICP) respectively, 111.9 (cf. accommodation) and 99.3 (cf. transport service)—countries with individuals using websites/apps to arrange an accommodation or a transport service from another individual below the average have presented higher increases of the HICP—respectively, 114.7 (cf. accommodation) and 106.9 (cf. transport service). Not surprisingly, price variations display their impact on consumption expenditure only if the economic wellbeing of households is at risk. Otherwise stated, the gross debt-to-income ratio of households represents a sufficient macroeconomic "brake" to excessive spending and an incentive to share certain goods and services. Upward trends of the HICP are already "incorporated" in the gross debt-to-income ratio of households because - if consumers are already indebted above the average- they will not additionally care about price increases. In the meantime, consumers will have adjusted their consumption patterns. 
Table 1. The macroeconomic relation between the gross debt-to-income ratio and individuals using websites/apps to arrange an accommodation or a transport service: the European case.

\begin{tabular}{|c|c|c|c|c|c|c|c|}
\hline \multicolumn{2}{|c|}{$\begin{array}{c}\text { Local Individuals Using } \\
\text { Websites/Apps to Arrange an } \\
\text { Accomodation from Another } \\
\text { Individual }\end{array}$} & \multirow{2}{*}{$\begin{array}{c}\begin{array}{c}\text { Gross Debt- } \\
\text { to-Income } \\
\text { Ratio of } \\
\text { Households }\end{array} \\
174(2018)\end{array}$} & \multirow{2}{*}{$\begin{array}{c}\begin{array}{c}\mathrm{HICP}- \\
\text { Accomodation } \\
\text { Services }\end{array} \\
106\end{array}$} & \multicolumn{2}{|c|}{$\begin{array}{l}\text { Local Individuals USING } \\
\text { Websites/Apps to Arrange a } \\
\text { Transport Service from } \\
\text { Another Individual }\end{array}$} & \multirow{2}{*}{$\begin{array}{c}\begin{array}{c}\text { Gross Debt- } \\
\text { to-Income } \\
\text { Ratio of } \\
\text { Households }\end{array} \\
66\end{array}$} & \multirow{2}{*}{$\begin{array}{c}\text { HICP- } \\
\text { Transport } \\
\text { Services }\end{array}$} \\
\hline Luxembourg & 46 & & & Estonia & 29 & & \\
\hline Ireland & 34 & 112 & 120 & Ireland & 26 & 112 & 101 \\
\hline Belgium & 26 & 104 & 117 & Iceland & 23 & 162 & 69 \\
\hline Switzerland & 26 & $190(2018)$ & 97 & Luxembourg & 22 & $174(2018)$ & 103 \\
\hline Estonia & 25 & 66 & 114 & Croatia & 17 & 54 & 98 \\
\hline France & 25 & 98 & 111 & Slovakia & 15 & 69 & 106 \\
\hline Spain & 24 & 93 & 115 & Switzerland & 15 & $190(2018)$ & 102 \\
\hline Sweden & 24 & 162 & 112 & France & 14 & 98 & 102 \\
\hline $\begin{array}{l}\text { United } \\
\text { Kingdom }\end{array}$ & 24 & 123 & 113 & Lithuania & 14 & 36 & 112 \\
\hline Hungary & 23 & 33 & 118 & Spain & 11 & 93 & 99 \\
\hline Netherlands & 23 & 191 & 122 & Netherlands & 9 & 191 & 109 \\
\hline Germany & 22 & 85 & 110 & Norway & 9 & 203 & 115 \\
\hline Iceland & 22 & 162 & 123 & Belgium & 8 & 104 & 107 \\
\hline Italy & 21 & 62 & 104 & Denmark & 8 & 214 & 110 \\
\hline Slovakia & 21 & 69 & 109 & Latvia & 8 & 32. & 99 \\
\hline Poland & 20 & 58 & 108 & Finland & 8 & 114 & 100 \\
\hline Croatia & 19 & 54 & 104 & Sweden & 8 & 162 & 107 \\
\hline Norway & 18 & 203 & 108 & Poland & 7 & 58 & 98 \\
\hline Finland & 15 & 114 & 126 & Slovenia & 7 & 44 & 100 \\
\hline Greece & 14 & 83 & 115 & United Kingdom & 7 & 123 & 118 \\
\hline Lithuania & 14 & 36 & 106 & Czechia & 6 & 59 & 96 \\
\hline Austria & 14 & 83 & 112 & Italy & 6 & 62 & 114 \\
\hline Portugal & 14 & 93 & 122 & Hungary & 6 & 33 & 102 \\
\hline Denmark & 11 & 214 & 116 & Portugal & 4 & 93 & 102 \\
\hline Romania & 9 & 24 & 110 & Romania & 4 & 24 & 110 \\
\hline Slovenia & 9 & 44 & 115 & Germany & 3 & 83 & 107 \\
\hline Latvia & 8 & 32 & 101 & Austria & 3 & 83 & 103 \\
\hline Czechia & 5 & 57 & 109 & Greece & 2 & 83 & 116 \\
\hline Cyprus & 5 & 134 & 109 & Cyprus & 2 & 134 & 78 \\
\hline Turkey & 3 & 25 (2017) & 142 & Turkey & 1 & 25 (2017) & 146 \\
\hline \multirow{2}{*}{ Average } & \multirow{2}{*}{18.8} & $\begin{array}{l}108.0(\text { if } \\
\text { individuals } \\
>18.8)\end{array}$ & $\begin{array}{l}111.9 \text { (if } \\
\text { individuals } \\
>18.8)\end{array}$ & \multirow{2}{*}{ Average } & \multirow{2}{*}{10.1} & $\begin{array}{l}105.4(\text { if } \\
\text { individuals } \\
>10.1)\end{array}$ & $\begin{array}{c}99.3 \text { (if } \\
\text { individuals } \\
>10.1)\end{array}$ \\
\hline & & $\begin{array}{l}87.8 \text { (if } \\
\text { individuals } \\
<18.8)\end{array}$ & $\begin{array}{l}114.7 \text { (if } \\
\text { individuals } \\
<18.8)\end{array}$ & & & $\begin{array}{l}96.2 \text { (if } \\
\text { individuals } \\
<10.1)\end{array}$ & $\begin{array}{l}106.9 \text { (if } \\
\text { individuals } \\
<10.1)\end{array}$ \\
\hline
\end{tabular}

Own elaboration based on [22-24].

\subsection{Macroeconomic Considerations about the Status Quo of the Sharing Economy in Europe}

We could clearly further deepen specific macroeconomic dynamics. For instance, Table 1 seems to confirm consumers' propensity to arrange an accommodation from another individual than a transport service, which endorses our previous claim that "shared" goods and services should be available at the local level, but also that individuals are possibly more prone to share goods and services not implying an excessive shortening of the interpersonal distance with unknown people. For sake of the present paper, it suffices to remark that production, final consumption expenditure and private debt trends are macroeconomically inter-related. At the same time, "[t]o recover from the COVID-19 crisis, Europe needs to unlock new economic activity" [25] with the concept of "sharing economy" likely gaining relevance in the near future. Moreover, European countries will have to face the fact that "the EU appears to be lagging behind the US when it comes to digitalization" [26]. Although individuals using the Internet in the European Union in 2020 
have been 87.9 percent of the total population [27], this figure is not far from the United States (89.4 percent) [28], and this is not a sufficiently precise indicator. On the one hand, it is not only the access to the Internet, which makes sharing of goods and services possible, because "[d]igital platforms are [rather] the key element of the collaborative economy" [29]. Moreover, according to [30], "[m]anagement technologies could be of significant valueadded, while strategic collaboration via digital hubs could help share knowledge with more advanced organizations, gather community, engage society, and create the desired synergy effect among stakeholders". A part of the economic literature also reminds us that European countries treat the sharing economy-more precisely, they draw the line between professional and nonprofessional providing of goods and services-in an often significantly different way than their neighbors [31]. While individuals make more or less frequent use of shared goods and services, the European economy as a whole has not yet been able to generate a truly incentivizing environment for investing companies. While some goods and services are shareable from consumers to consumers (C2C), the most relevant opportunities in terms of contribution to GDP are represented by those from businesses to consumers (B2C) [32]. According to [33], in 2016 more than 275 companies belonging to the "collaborative economy" have been founded across nine major European countries. Although the United Kingdom and France counted more than 50 organizations, Germany, Spain and the Netherlands ranked at more than 25 companies while countries like Belgium, Italy, Poland and Sweden counted only less than 25 organizations. Among the reasons for the growth of targeted platforms, there is "flexibility, smartphones; a shift from valuing ownership to renting; and growing digital trust, lax regulations [and] operational efficiency" [34]. This has caused a rapid increase of revenues in the European Union from approximately $€ 1 \mathrm{bn}$. to $€ 3.6 \mathrm{bn}$. in the time period 2013-2015 [35]. As more specifically outlined by [36], "the sustainable development of car-sharing services is influenced not only by operators, but also by local authorities and local market conditions".

Furthermore, such structural characteristics have to be considered also from a public policy perspective. If "[h]ousehold consumption is the largest element of expenditure across the economy" [37], but as the main GDP component it is subject to new patterns and characterized by different typologies of consumers, governments should care too. For instance, it has to be questioned whether public incentivizing and/or subsidizing the purchase of specific goods and services-let us mention, for sake of simplicity, cars (including e-cars [38]) are still adequate both in terms of consumption paradigms and sustainability. The COVID-19-pandemic has caused a partial, exogenous stop to the sharing economy, which has been due to lockdowns and psychological fears deriving from contagion risks [39-42]. While taking a public transport service before February/March 2020 was considered a cheap way to reduce the environmental footprint of individuals, after worldwide contagions, taking his/her own car was perceived as "safe" while the sustainability-related aspect became secondary. Will this be an enduring trend? Probably not because macroeconomic variables affecting consumer trends and concerns about the environmental sustainability of traditional consumption patterns will prevail. However, the sharing economy has to be explored in its complexity due to heterogeneous and emergent ways of consumption in digitally advanced eras. The next section is, therefore, dedicated to the in-depth analysis of these paradigms.

\subsection{Liquid and Solid Consumption in the Sharing Economy}

Advantages and opportunities for individuals brought by the sharing economy are often paired with another trend in consumption: liquid modernity [2]. In this context of modernization and digitalization, consumers adopt a slightly different approach to consumption that [4] defined "liquid". Liquid consumption is ephemeral, access-based and dematerialized. Liquid consumption is opposed to solid consumption that is enduring, ownership-based and tangible. Ownership is strictly connected with use, control, and the possibility to convey the good to others [43]. Ownership communicates meanings and is frequently used by consumers to build their identity [44] as well as a signaling 
mechanism for success and wealth. Moreover, ownership leads to consumer responsibility and commitment: maintenance, storage, and divestiture of unwanted goods [45] as well as obsolescence or a value decrease are just examples of the negative side of ownership.

Conceptually opposed to consumption models based on ownership, the liquid one is traditionally an access-based model. In fact, consumers in the access-based model pay for access to goods instead of buying those goods and prefer to pay a price for temporarily having the access to the goods [3]. The access-based consumption model is more and more popular nowadays for individuals; in most cases, it is more profitable and convenient for consumers to pay for temporary access to product (e.g., renting) rather than owning it [46]. More specifically, as [3] pointed out, the two models of consumption (ownership versus access-based) differ for two characteristics: (1) the nature of the object-self relationship and (2) the rules regulating such relationships. When consumers adopt an access-based model, they are aware that their disposal of the good is limited in time and connected to specific consumption situations. On the contrary, when adopting the ownership model, individuals embrace a long-term orientation planning how to dispose of the object over time. In terms of how the relationship with the object is regulated, individuals choosing the access-based consumption option cannot regulate the access to it preventing other consumers from (over)using it. This, on the opposite, is a privilege that only owners enjoy.

The access-based consumption model has recently gained in popularity: in the past decades, it was considered inferior as compared to the more traditional property model. This perception was due to the idea that consumers not able to buy and own a good would prefer to rent it. These consumers were socially stigmatized and considered not capable of saving and allocating their expenditures and therefore not worth the social power intrinsically tight to ownership. Today, on the contrary, access-based models of consumption are very popular thanks also to a shift in the paradigm and public opinion. Firms, thanks to digitalization, guarantee access to their products on a daily basis, while the development of a liquid society [1] fostered this change. In this scenario, liquid consumption emerges [4]. Liquid consumption is a more comprehensive paradigm than the access-based, which does not substitute solid consumption. More specifically, consumption is conceptualized as a continuum of alternatives faced by consumers ranging from pure solid to pure liquid. Therefore, solid and liquid consumption are two extreme poles of a spectrum [4]. Among the conditions that foster one form of consumption over the other, the same scholars identify: relevance to the self, nature of social relationship, accessibility to mobility and the nature of precarity.

Specifically, authors posit that, when relevance to the self is high, consumption will be more solid. It is the identification with the good which drives the relevance for the self. In those cases in which the good contributes to the formation of the consumer identity (e.g., extended self as in $[47,48]$ ), then consumers will prefer the ownership option while consumption will be more solid. Such a relationship is based on a long-term attachment with a product or brand [49], thus emphasizing the relevance of brand loyalty in predicting the position of individuals in the solid-liquid continuum. On the contrary, when the identification of the item is not fundamental for the consumers, they will prefer a more liquid mode of consumption. Although this is not good-specific, it varies with individuals and the level of importance, which the good has for them. For example, in the music industry, there are collectors very passionate about owing the CD or the vinyl of their favorite bands, so they would identify with a typical solid consumption model; at the same time, there are thousands of consumers, who have switched completely to streaming options for music. These consumers enjoy the benefits of online platforms such as Spotify and prefer to pay a subscription fee, which is in turn typical of a liquid consumption model.

The second characteristic driving a solid versus liquid consumption mode is the nature of social relationships. Whenever relationships are strong, consumption is supposed to be more solid. This is the case, for example, of brand communities [4] in which consumers sometimes even embody their brands. However, the relationship between brand loyalty and liquid consumption is already under debate. Access-based consumption, as a com- 
ponent of the liquid side, allows consumers to test new products and trends avoiding the barriers of ownership and commitment to a specific style or brand. Moreover, even if brand loyalty represents a deterrent to access-based consumption because of a lack of past experience, this could become a new way to determine exactly their preferences and to regulate them in a context qualified by high level of product variety. Moreover, trust towards providers of functions or services-as providers of goods in the liquid side of consumption-has been seen as a critical element in forming attitudes towards this form $[50,51]$. Under this perspective, liquid consumption could be positively associated with brand loyalty, being an alternative route to product and brand loyalty [52].

Access-based consumption is associated with a higher degree of environmental consciousness. Frequently linked to a cheap and easy way to access expensive products, the access-based model is considered a way to be environmentally friendly [53]. Indeed, as [46] suggests, this consumption model is one of the main components of a more sustainable and responsible consumption. In addition, policymakers also support access-based model of consumption because of its positive impact on the environment, thus highlighting the link between more liquid consumption and benefits for the environment [50].

Another driver of consumption models are mobility systems, which are organized in cities around the mechanisms and allow people to circulate in different spaces at different speeds. These networks, which are highly de-territorialized, are common in global cities. When consumers have access to these networks, consumption can be liquid; when access to mobility networks is instead limited, consumption is mostly solid. This is the typical example of car sharing. In global cities, car sharing is a very frequent and common method of moving across the city; moreover, it allows citizens to have the possibility to access to a car (e.g., liquid consumption) rather than owning it (e.g., solid consumption).

The last factor is precarity and represents the extent to which individuals feel insecure, instable and uncertain. When individuals perceive high levels of precarity, they tend to use consumption as a way to restore certainty. Therefore, they prefer to engage in solid purchases. When the situation and context they experience in their daily lives are relatively stable, individuals do not feel the need to restore any level of certainty and stability. Therefore, they are more prone to engage in liquid consumption.

So far, previous research contributions $[3,4,52,54-56]$ have highlighted the contextual and situational factors having an influence in driving individuals towards solid versus liquid form of consumption. To the extent of our knowledge, little is known about the individual motivations that drive consumers' choice.

Grounding on the characteristics of solid and liquid consumption, this study aims at shedding lights on psychological and behavioral characteristics at the individual level that can foster a more solid versus more liquid form of consumption. More specifically, if solid and liquid consumption are the two extremes of a spectrum, what are the psychological characteristics inducing individuals to engage more in a consumption form over the other?

According to Agenda 2030 goals, the rise of environmental consciousness represents a key goal for the success of the whole program. Indeed, as recent research conducted by [57] has highlighted that "the majority (73\%) of global consumers say they would definitely or probably change their consumption habits to reduce their impact on the environment". Such environmental consciousness is an antecedent of environmentally friendly behaviors [58,59], and access-based consumption, as one of the possible facets of liquid consumption, could represent the right solution for consumers characterized by a high level of environmental consciousness. Access-based products offer consumers the opportunity to adopt practices that are more environmentally friendly, targeting those individuals that are motivated mostly by an efficient resource's exploitation and the willingness to contribute to waste reduction.

Focusing on shared mobility, previous research finds an unclear role of environmental consciousness for consumers' decision to engage in car sharing having [60] found that sustainable concerns were not among the priorities of consumers engaging in B2C carsharing services. However, a fast change in consumer habits has been recently noted. According 
to [61], "[t]he image of carsharing in general is "greener" thus showing how environmental concerns affect the decision to engage in P2P service over B2C services. Recently, ref. [62] finds that environmentalism has a positive effect on providers' and users' propensity to participate in peer-to-peer shared mobility services. To this purpose, investigating the psychological characteristics that might lead individuals to engage in more liquid consumption is fundamental to identify was to incentive a more sustainable consumption. Emotions and especially happiness can have a strong influence over choice too. Indeed, being in a positive mood affects individuals' cognitive processing, thus influencing the types of choices individuals make. Under this perspective, individuals that are in a positive mood are more likely to engage in heuristic processing [63] or to develop an optimistic view over the future [64], or to evaluate people and objects more favourably [65]. Positive mood influences choice, leading individuals to choose less risky options [66] and greater variety among different choices. Moreover, when an individual lays in a positive mood condition tend to make healthier choices both in terms of food, lifestyle, and professional life. A positive mood increases the perception of value for items owned both actually or potentially. Such an effect occurred in judgments about both actual and potential possessions, suggesting that people tend to overestimate the value given to their material possession depending on how they are feeling in that time. All in all, we posit that environmentalism, brand loyalty, risk propensity, and variety seeking well-being could be seen as antecedents and motivation underlined by the consumer in a solid versus liquid state of consumption.

\section{Materials and Methods}

In order to answer to the research question, our empirical research is based on a survey (Figure 2). Moreover, the goal of the survey is to identify typologies of consumers that, according to psychological characteristics, are placed differently on the solid versus liquid continuum. By means of a cluster analysis, we will identify profiles of consumers that differ in terms of proneness to liquid versus solid consumption.

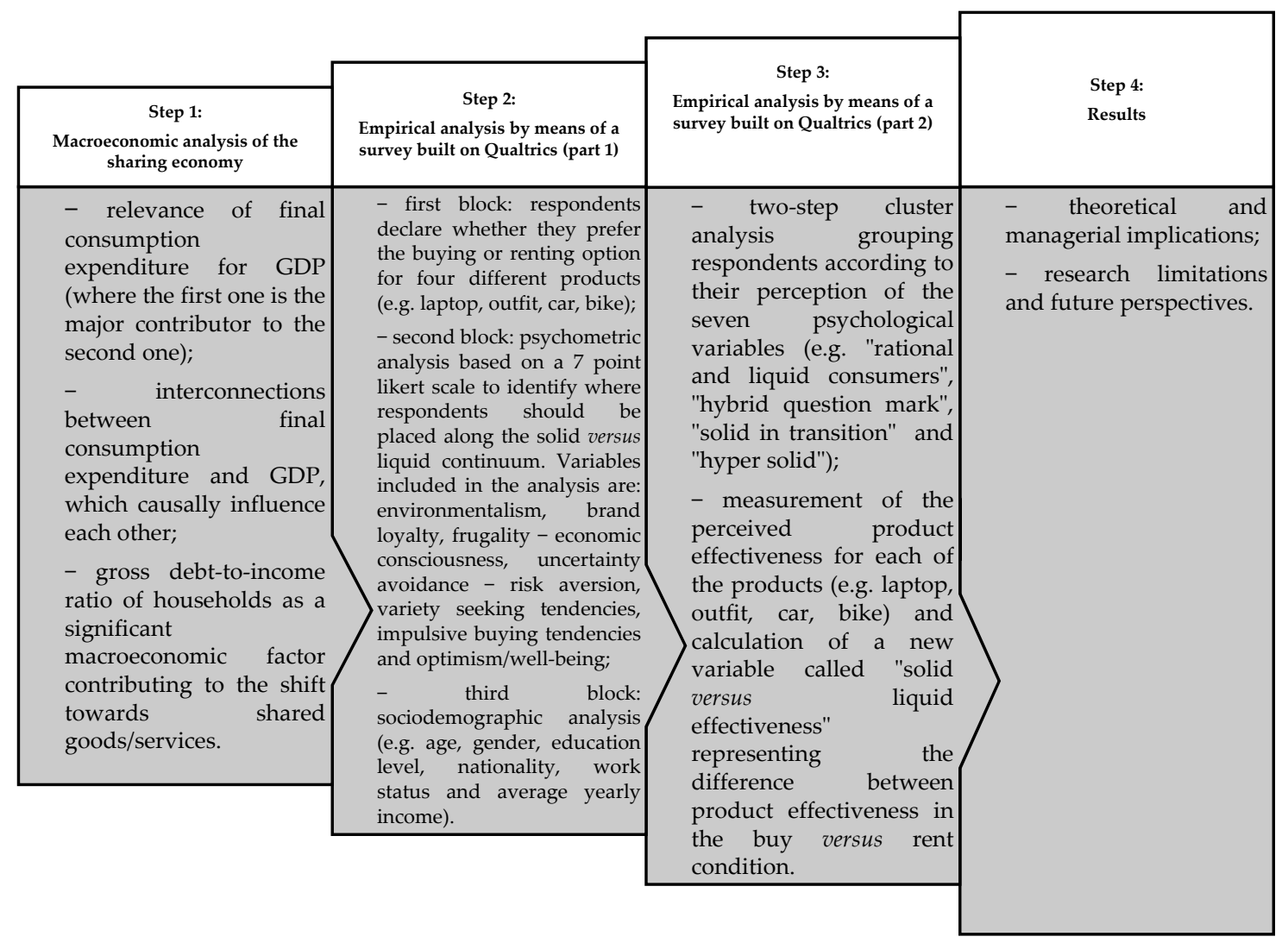

Figure 2. Flow diagram illustrating the analytical process. 
The survey (Appendix A), built on Qualtrics, is structured in three different blocks. The first block is composed of four different scenarios aimed at helping respondents immerse into the context of the research and to identify whether they prefer more the buying versus renting options for products. More specifically, each scenario described a specific product (e.g., laptop, outfit, car, bike) and presented a brief description of the product together with the option of buying the product or renting it. In addition, price ranges for both options were presented while all the four scenarios were presented to respondents. The second block of the survey was composed by seven psychometric scales that aimed to classify respondents as solid, liquid or intermediate. All the scales, were measured on a 7 points Likert scale ranging from $1=$ totally disagree to $7=$ totally agree. Specifically, the scales employed in the survey aim at measuring psychological characteristics of the individuals in order to be able to place them along the solid versus liquid continuum. More precisely, as listed in Table 2, the variables included in the analysis were as follows:

(1) Environmentalism [67]: according to [52], a factor that prompts liquid consumption is the environmental consciousness. Access-based consumption is based on the idea of a more efficient use of resources and waste reduction. In the sharing economy paradigm, the attention shifts from the product to the sharing opportunity offered to consumers that can still satisfy their needs without buying the product. The growing consumers' desire to engage into sustainable consumption is thus fundamental in driving more liquid purchasing choices;

(2) Brand loyalty [68]: loyal consumers who belong to brand communities or communities of fans are driven by their long-term attachment towards the brand [49,69]. Moreover, this is typical of solid consumption. At the same time, liquid consumers are not loyal and are characterized by a short-term orientation [4];

(3) Frugality-economic consciousness [70]: frugality is defined as "a unidimensional consumer lifestyle trait characterized by the degree to which consumers are both restrained in acquiring and in resourcefully using economic goods and services to achieve longer-term goals" [70]. This represents a fundamental construct to analyze consumption and purchasing habits, especially when faced with environmental implications like in the context of the sharing economy;

(4) Uncertainty avoidance-risk aversion [71]: risk aversion describes the extent to which individuals feel threatened by unknown and ambiguous situations. When risk aversion is high, individuals feel the need to reduce it by preferring certain, fixed and rigid rules. Therefore, they prefer a more solid type of consumption. When risk aversion is low, individuals are able to tolerate a certain degree of uncertainty [72] and are more prone to liquid consumption;

(5) Variety seeking tendencies [73]: a variety seeking behavior is defined as a tendency to look for diversity in consumption choices [74]. It arises specifically when individuals are satiated and therefore experience a need to change. Grounding on this assumption, liquid consumption allows consumers to change and try different options without a long-term commitment;

(6) Impulsive buying tendencies [71]: this variable is defined as the extent to engage into unplanned purchasing decisions. This personality trait is usually correlated with materialism and variety seeking [71]. It is, therefore, reasonable to expect that individuals with a more solid consumption style are more prone to engage in impulsive buying;

(7) Optimism/well-being [75]: according to [65] property has an affective dimension. According to the affective infusion model, positive and optimistic mood induces individuals to evaluate goods more positively and even over-evaluate them, preventing individuals from detaching from the object. This attitude might foster a solid approach to consumption. 
Table 2. Survey scales and reliability.

\begin{tabular}{|c|c|c|c|}
\hline Construct & Operationalization & Source & Cronbach's Alpha \\
\hline $\begin{array}{l}\text { Environmentalism-Purchasing } \\
\text { behavior }\end{array}$ & $\begin{array}{l}\text { 1. It is important to me that the products I use do not } \\
\text { harm the environment. } \\
\text { 2. I consider the potential environmental impact of } \\
\text { my actions when making many of my decisions. } \\
\text { 3. My purchase habits are affected by my concern for } \\
\text { our environment. } \\
\text { 4. I am concerned about wasting the resources of our } \\
\text { planet. } \\
\text { 5. I would describe myself as environmentally } \\
\text { responsible. } \\
\text { 6. I am willing to be inconvenienced in order to take } \\
\text { actions that are more environmentally friendly. }\end{array}$ & [67] & 0.918 \\
\hline Brand loyalty & $\begin{array}{l}\text { 1. After I get used to a brand, I don't like to switch. } \\
\text { 2. I see myself as a brand loyal person. } \\
\text { 3. I feel really committed to the brands I buy. } \\
\text { 4.> Even though certain products are available in a } \\
\text { number of different brands, I always tend to buy the } \\
\text { same brand } \\
\text { 5. I prefer the brand I always buy instead of trying } \\
\text { something new I am not sure about. }\end{array}$ & {$[68]$} & 0.881 \\
\hline Frugality (economic consciousness) & $\begin{array}{l}\text { 1. If you take good care of your possessions, you } \\
\text { will definitely save money in the long run. } \\
\text { 2. There are many things that are normally thrown } \\
\text { away that are still quite useful. } \\
\text { 3. Making better use of my resources makes me feel } \\
\text { good. } \\
\text { 4. If you can re-use an item you already have, there's } \\
\text { no sense in buying something new. } \\
\text { 5. I believe in being careful in how I spend my } \\
\text { money. } \\
\text { 6. I discipline myself to get the most from my money. } \\
\text { 7. I am willing to wait on a purchase I want so that I } \\
\text { can save money. } \\
\text { 8. There are things I resist buying today so I can save } \\
\text { for tomorrow. }\end{array}$ & {$[70]$} & 0.836 \\
\hline
\end{tabular}

1. I tend to avoid talking to strangers.

2. I prefer a routine way of life to an unpredictable one full of change.

Uncertainty avoidance (risk aversion) 3. I would not describe myself as a risk-taker.

4. I do not like taking too many chances to avoid making a mistake.

5. I am very cautious about how I spend my money.

1. If something can go wrong for me, it will.

2. I'm optimistic about my future.

Optimism

3. I hardly ever expect things to go my way.

4. I rarely count on good things happening to me.

5. Overall, I expect more good things to happen to me than bad

1. I enjoy taking chances by trying out unfamiliar companies, products/contracts to provide variety to my life.

Variety seeking tendencies

2. I like trying things out that I am not familiar with.

3. I always try something different. 
Table 2. Cont.

\begin{tabular}{|c|c|c|c|}
\hline Construct & Operationalization & Source & Cronbach's Alpha \\
\hline Impulsive buying tendencies & $\begin{array}{l}\text { 1. I often spend more than what I can afford. } \\
\text { 2. I like to indulge myself by buying things for } \\
\text { pleasure. } \\
\text { 3. I lose self-control quite frequently. } \\
\text { 4. I often act without thinking about the } \\
\text { consequences. } \\
\text { 5. I seldom plan anything in advance. } \\
\text { 6. I often make decisions spontaneously. }\end{array}$ & [71] & 0.789 \\
\hline
\end{tabular}

Finally, the third block of the survey included sociodemographic questions on respondents such as age, gender, education level, nationality, work status and average yearly income.

\section{Results}

A total of 242 responses were collected using prolific academic, an online platform for recruiting participants for studies, therefore the sample selection is random. The sample is mainly composed of males $(n=121)$. All of the age ranges are represented in the full data set, although there is a stronger concentration in the age groups spanning from 18 to 24 years ( $54.5 \%$ of the sample, see Appendix A for more data on the sample). In terms of education and occupation, there is a good spread across the categories listed. As a preliminary step, all scales measured with a Likert scale ranging from 1 ("strongly disagree") to 7 ("strongly agree") were checked for their reliability. Afterward, items for each scale were averaged so as to create one single indicator for each construct (Table 2).

After this preliminary process, a two-step cluster analysis was performed to categorize sample respondents on the basis of their responses to the clustering variables [71], specifically the seven psychometric scales. Therefore, the criteria employed for clustering the participants were the average score on the seven scales. The initial, hierarchical cluster analysis suggested a four clusters solution. Then, we used a nonhierarchical k-means clustering procedure [77] to develop the four-clusters solution. While doing so, respondents were grouped according to their perception of the seven psychological variables (Table 3). Analyses of variance was also conducted to compare the four clusters.

Cluster 1 includes "Rational and liquid consumers", who show the highest preference for renting solutions for all products tested. This cluster is mainly characterized by high frugality and risk aversion, showing also high score on the environmental purchasing behavior traits. More specifically, this cluster represents consumers that are well aware of the potential negative consequences of their consumption choices and therefore decide to adopt a more conscious and sustainable approach to product choice. Surprisingly, this cluster accounts for high score in the brand loyalty trait while it scores lowest on the traits of impulsive buying tendencies.

Cluster 2 is composed of behaviorally "hybrid" individuals labeled "Hybrid question marks". Frugality, environmental purchasing behavior, and variety seeking are the three main traits that qualify consumers belonging to this segment. On the contrary, they exhibit the lowest level of optimism and a relatively low degree of impulsive-buying tendencies. This cluster represents the individuals that are well aware of their priorities in terms of consumption choices but that still need to fill the gap with actual behaviors. Therefore, as the results show, they are very clear on the intentions side but their actions do not fully follow their ideas yet.

Cluster 3 is composed of consumers solid in their behavior but already in transition towards a more solid state. Therefore, this cluster has been labeled "Solid in transition". This segment is significantly more concerned about frugality, variety seeking, and optimism, whereas brand loyalty assumes the lowest score across the four clusters. This group of 
individuals are those that are starting to change their minds and might start to receive information for embracing a more sustainable approach to consumption.

Table 3. Clusters description.

\begin{tabular}{ccccc}
\hline Cluster & $\begin{array}{c}\text { Rational and } \\
\text { Liquid }\end{array}$ & $\begin{array}{c}\text { Hybrid } \\
\text { Question Marks }\end{array}$ & $\begin{array}{c}\text { Solid in } \\
\text { Transition }\end{array}$ & Hyper Solid \\
\hline Number/percentage & 69 & 71 & 54 & 48 \\
\cline { 2 - 5 } & $(29 \%)$ & $(29 \%)$ & $(22 \%)$ & $(20 \%)$ \\
\hline $\begin{array}{c}\text { Environmentalism- } \\
\text { purchasing } \\
\text { behavior }\end{array}$ & 5.20 & 5.54 & 4.26 & 4.20 \\
\hline Brand loyalty & 5.38 & 3.73 & 3.31 & 4.69 \\
\hline $\begin{array}{c}\text { Frugality (economic } \\
\text { consciousness) }\end{array}$ & 6.29 & 6.18 & 5.79 & 4.35 \\
\hline $\begin{array}{c}\text { Uncertainty avoidance } \\
\text { (risk aversion) }\end{array}$ & 5.51 & 4.17 & 4.64 & 2.98 \\
\hline Well-being & 3.22 & 2.37 & 4.88 & 4.25 \\
\hline $\begin{array}{c}\text { Variety seeking } \\
\text { tendencies }\end{array}$ & 3.65 & 5.34 & 4.92 & 4.24 \\
\hline $\begin{array}{c}\text { Impulsive buying } \\
\text { tendencies }\end{array}$ & 2.84 & 3.11 & 3.59 & \\
\hline$(n=242)$. & &
\end{tabular}

Cluster 4 is composed of solid consumers, mainly attracted by buying solutions and is labeled "Hyper solid". Individuals belonging to this cluster are brand loyal, frugal, and with a lower score on variety seeking and impulsive buying behavior. This cluster shows the lowest score on environmental purchasing behavior, suggesting that the higher is the solid state of consumption, the higher will be the aversion to environmentally friendly behavior and consciousness.

Finally, we measured the perceived product effectiveness for each of the four products assessed within the survey using the score as a behavioral descriptor for each cluster. In further detail, we asked each respondent to evaluate, on a seven-point Likert scale, the effectiveness of the solution - in the buy or rent condition - using the Product Evaluation scale [78]. A new variable has then been calculated as the difference between product effectiveness in the buy versus rent condition named "Solid versus liquid effectiveness" (SLE). The higher the score, the higher the perceived effectiveness for the buy solutions. When the score is negative, the respondent is mainly oriented to the rent solutions in the majority of the four conditions tested (Table 4).

Table 4. Solid versus liquid effectiveness.

\begin{tabular}{ccccc}
\hline Cluster & Hyper Liquid & $\begin{array}{c}\text { Hybrid } \\
\text { Question Marks }\end{array}$ & $\begin{array}{c}\text { Solid in } \\
\text { Transition }\end{array}$ & Hyper Solid \\
\hline Number/percentage & 69 & 71 & 54 & 48 \\
\cline { 2 - 5 } & $(29 \%)$ & $(29 \%)$ & $(22 \%)$ & $(20 \%)$ \\
\hline $\begin{array}{c}\text { Product } \\
\text { effectiveness }\end{array}$ & -8.68 & 4.75 & 8.02 & 21.44 \\
\hline
\end{tabular}

To provide the descriptive profiles for the four segments, a one-way ANOVA was performed. The cluster membership variable generated in the k-mean cluster analysis formed the independent variable and the solid versus liquid effectiveness variable together with the demographic characteristics were used as the dependent variables to describe 
each segment and to determine their statistical significance. This test showed that solid versus liquid effectiveness (f-stat. $4.331, \mathrm{df}=3, p<0.005$ ) was significant.

\section{Discussion and Conclusions}

From a macroeconomic perspective, the paper highlights by means of a theoretical approach some of the structural elements at the basis of the sharing economy. Of particular interest is, moreover, the identification of the statistical item "gross debt-to-income ratio of household" as a "nudge" towards arranging services like accommodation and transport services from another individual (Table 1). Clearly, more and more far-reaching statistical data are needed to verify whether this macroeconomic nexus will remain equally strong in a "high-debt environment" [79] like the one after the global financial crisis (2007-2008) and the COVID-19 pandemic (2020-).

At the same time, the main objective of the empirical research was to better understand the continuum between solid and liquid consumption. Looking precisely at individual and psychological characteristics at the individual level, we shed light on the motivations that might induce consumers to engage in a more solid versus liquid consumption approach. This is, to the extent of our knowledge, a first attempt to measure individuals' profiles on the solid versus liquid continuum. As of now, previous research has mainly focused on assessing the impact of contextual variables in shaping individuals' preferences towards the liquid/solid dichotomy. Our work builds and extends these findings by shifting the unit of analysis from the context to the individual and so providing a typology of individuals that differ in terms of psychological and behavioral variables. Our findings provide several theoretical and practical contributions to academics, brand managers, and sustainability managers.

\subsection{From Macroeconomics to the Survey Analysis}

Our work begins with outlining some of the macroeconomic reasons at the origin of the sharing economy. Although this part is not at the core of our research (which is based on a survey), it is particularly relevant because it analyses some often-neglected economic variables like the gross debt-to-income ratio of households and their interconnections with the sharing economy. Preliminarily, understanding consumption from a broader (i.e., macroeconomic and GDP-related) perspective and, secondarily, tighten the focus from a more microeconomic and behavioral angle of view while looking at some of its solid versus liquid characteristics appears to be particularly helpful. In fact, the survey aims at investigating the individual and psychological characteristics in support of more solid versus more liquid forms of consumption. Moreover, if solid and liquid consumption are the two poles of a spectrum, our approach from a more macro- to a more micro-level reflects this continuum.

\subsection{Theoretical Implications}

The study presents several theoretical contributions. First, this study broadens researchers' current knowledge on individual differences affecting consumers' journey from a liquid to a more solid state of consumption. Such an approach contributes to the existing debate in consumer research showing how solid or liquid consumption are just labels, with individuals always positioned between one of those points. Environmentalism (i.e., the degree of environmental consciousness) and frugality emerge in our analysis as the most relevant dimensions to discriminate customers in terms of liquid or solid condition. These can be considered like antecedents of the liquid state such that the higher is their score the higher will be the willingness to choose access-based solutions because the latter are perceived as more sustainable and environmentally friendly. The identification of two antecedents of solid versus liquid consumption is a major theoretical contribution of this work to the existing literature on the topic because, to the extent of our knowledge, there is no clear empirical evidence on the drivers of solid versus liquid consumption. 


\subsection{Managerial Implications}

Our findings have several managerial implications that help brand and sustainability managers to better understand the transition that consumers are now experiencing, turning gradually their preferences from a solid and relatively stable base to a liquid and contestable one. Under this perspective, the proposed segmentation could assist managers in the understanding of the motivation underlined by a more solid versus liquid approach to consumption, looking at brand awareness and brand loyalty as a key service dimension for a better and wider diffusion of access-based solutions.

At the same time, the dimension of the two clusters in transition suggests that a great majority ( $58 \%$ of the total sample) of the potential customers is still exploring nonbuying solutions looking for better awareness and trustworthiness. These are consumers that companies can easily target with specific communication campaigns that emphasize even more the benefits of liquid consumption such as the positive externalities for the environment, for the individual and for the society at large.

Moreover, looking at customers like hybrid question marks-the second clustercould have some positive network externalities. Being the second one in terms of environmentalism purchasing behavior, this cluster could positively affect a sustainable approach to goods and services consumption. This cluster should become the target priority of both firms already adopting an access-based business model and policymakers who want to foster a more sustainable approach to consumption. In particular, it could be emphasized that the dematerialization in general saves $\mathrm{CO}_{2}$ and green house gas emissions by lessening the manufacturing demand of certain products [80]. The idea of ownership versus access-based consumption also plays a role.

Access-based consumption reserves use of something for when it is needed the most, and it is therefore being used in the most efficient manner. This is a clear benefit that companies offering this type of consumption mode can emphasize. In addition, it is important to highlight to consumers the positive implications for the environment that access-based consumption brings forward. More in detail, reinforcing the importance of the end life of whatever product is being used. A large issue regarding sustainability is that often consumers do not pay attention to their waste management with things that they throw away less often (an old laptop, a car, an old oven, etc.). Sometimes individuals are not fully aware of how to dispose of their larger possessions in the most sustainable manner, so if these were only available in an access-based manner, the disposal can be reserved to the knowledge worker that specializes in this. Liquid consumption in general leads to waste reduction, which plays a large role in a more sustainable world [81].

Regarding modes of transportation, it is known that the most sustainable way for people to transit to work would be for every individual to use the public transport system. Of course, this is a stretch; however, the liquid consumption of the public transport system would not only decrease air pollution, but it would also decrease traffic congestion, noise pollution, and the long-term sustainability effects of owning a car (such as the disposal of it). Many people, like those identified in the cluster "Hyper Liquid" and "Hybrid question mark" are growing more aware of their environmental footprint and liquid consumption adequately should capitalize on that.

\subsection{Research Limitations}

As with any research, this study also suffers from some limitations that might impair the generalizability of the findings. First, the sample could be extended so as to increase the robustness of the analysis. Second, respondents to the survey were presented with four different scenarios regarding specific products. These scenarios could not apply to every potential consumer. Therefore, increasing the options available for the scenarios might increase the representativeness of the data. Third, the survey considers seven psychological and behavioral variables that, according to our understanding of the phenomenon, influence the individuals. Other psychological dimensions, such as materialism, could be included in the analysis to provide a more detailed profile of consumers. 
Author Contributions: Conceptualization, E.B., G.M. and F.R.; methodology, G.M. and F.R.; software, G.M. and F.R.; validation, G.M. and F.R.; formal analysis, G.M. and F.R.; investigation, G.M. and F.R.; resources, E.B., G.M. and F.R.; data curation, E.B., G.M. and F.R.; writing—original draft preparation, E.B., G.M. and F.R.; writing-review and editing, E.B., G.M. and F.R.; visualization, E.B.; supervision, E.B. and G.M.; project administration, E.B.; funding acquisition, E.B. All authors have read and agreed to the published version of the manuscript.

Funding: This research received no external funding.

Institutional Review Board Statement: Not Applicable.

Informed Consent Statement: Informed consent was obtained from all subjects involved in the study.

Data Availability Statement: Upon requests, data can be found on qualtrics.com, last accessed on 10 December 2021.

Acknowledgments: Our sincerest thanks go to Carlotta Montagna for her assistance in data collection and to the academicians, who have carefully read, reviewed and appreciated the article while contributing to its improvement at different stages. Any remaining errors are ours.

Conflicts of Interest: The authors declare no conflict of interest.

Appendix A

Demographic data of the sample (Table A1).

Table A1. Solid versus liquid effectiveness.

\begin{tabular}{|c|c|}
\hline \multicolumn{2}{|c|}{ Demographics } \\
\hline \multicolumn{2}{|c|}{ Age range } \\
\hline $18-24$ & $55 \%$ \\
\hline $25-30$ & $26 \%$ \\
\hline $31-35$ & $11 \%$ \\
\hline $36-40$ & $6 \%$ \\
\hline$>40$ & $2 \%$ \\
\hline \multicolumn{2}{|c|}{ Sex } \\
\hline Male & $50 \%$ \\
\hline Female & $49 \%$ \\
\hline Nonbinary/third gender & $1 \%$ \\
\hline \multicolumn{2}{|c|}{ Education } \\
\hline Less than high school & $1 \%$ \\
\hline High school diploma or equivalent degree & $45 \%$ \\
\hline Bachelor's degree & $38 \%$ \\
\hline Master's degree & $14 \%$ \\
\hline PhD or higher & $2 \%$ \\
\hline \multicolumn{2}{|c|}{ Income } \\
\hline$<€ 20,000$ & $56 \%$ \\
\hline$€ 20,000$ to $€ 70,0000$ & $26 \%$ \\
\hline$€ 70,000$ to $€ 100,000$ & $2 \%$ \\
\hline$>€ 100,000$ & $1 \%$ \\
\hline Prefer not to say & $14 \%$ \\
\hline
\end{tabular}

Appendix A.1. Survey's Scenarios

Appendix A.1.1. Scenario 1: Laptop

Imagine you are in the market to find a new laptop computer that fits your needs. After reviewing information online, speaking to your friends, and weighing your options you decide to go for a Microsoft Surface Pro. The Microsoft Surface Pro that you are going to get costs $\$ 1300.05$ to purchase. However, you can also decide to rent it for almost any length of time. The rental price ranges from a minimum of $\$ 26.35 /$ month to a maximum of $\$ 54.21 /$ month depending on the chosen duration $(60,48,36$ or 24 months). The price 
includes insurance coverage in case of breakdowns, accidental damage or theft. At the end of the rental, you can continue with lower installments, continue replacing the PC with a newer model, return it, or keep it by bearing the rental closing costs. Would you buy or rent the laptop?

(1) I would be satisfied with my decision to rent (buy) the Surface Pro and accessories;

(2) The choice to rent (buy) the Surface Pro and accessories would be a wise one;

(3) I think that I did the right thing when I decided to rent (buy) the Surface Pro and accessories;

(4) I feel good about my decision to rent (buy) the Surface Pro and accessories.

\section{Appendix A.1.2. Scenario 2: Outfit}

Imagine you are looking for an outfit to wear on a special occasion and after some research you jump into an online platform where you can rent fashion designer items. On this site you can browse a closet choosing from thousands of styles and designers going from $\$ 200$ up to $\$ 1500$ and you can decide to rent the item paying for a membership of around $\$ 65 / 100$ per month (depending on the chosen plan, regardless of the price of the item) or you can even decide to go for a one-time rental (see image below). If you are a member, you can send back as many items as you want at a time. You can pause or cancel your membership at any time for no extra cost, so you can buy a dress for the occasion wherever you want, spending at least \$200/300; otherwise you can decide to rent your outfit on the platform. Would you buy or rent the item that you are looking for?

(1) I would be satisfied with my decision to rent (buy) the fashion item;

(2) The choice to rent (buy) the fashion item would be a wise one;

(3) I think that I did the right thing when I decided to rent (buy) the fashion item;

(4) I feel good about my decision to rent (buy) the fashion item.

\section{Appendix A.1.3. Scenario 3: Car}

Imagine you are planning to get a car for your daily movings, and after reviewing some information and weighing your options, you decide to go for a station wagon. You are considering to purchase a Volkswagen or a Ford one for about $\$ 40,000+$ tax when you find out you can rent one even on an hourly basis through a car sharing platform. You can join three different membership plans, depending on your needs:

(1) Basic (best if you only drive occasionally): $\$ 0$ monthly rate, drive from $\$ 0.23 / \mathrm{min}$;

(2) Smart: $\$ 8.50$ monthly rate, drive from $\$ 0.18 / \mathrm{min}$;

(3) Plus: $\$ 21$ monthly rate, drive from $\$ 0.15 / \mathrm{min}$;

(4) The car sharing company covers gas, insurance options and parking. All you need is a driver license, a credit/debit card and a smartphone to book the car closer to you.

Would you buy or rent the station wagon you are looking for? (buy/rent)

(1) I would be satisfied with my decision to rent (buy) the car;

(2) The choice to rent (buy) the car would be a wise one;

(3) I think that I did the right thing when I decided to rent (buy) the car;

(4) I feel good about my decision to rent (buy) the car.

Appendix A.1.4. Scenario 4: Bike

Imagine you are planning to get a bike for your daily movings. After reviewing some information and weighing your options, you decide to go for one which is about $\$ 450$, when find out you can rent a top of range one thanks to a sharing platform. To rent the bike, you have to pay a $\$ 1$ fee to unlock the vehicle and then a $\$ 0.20 / \mathrm{min}$ rate. The sharing company covers maintenance, insurance options and parking. All you need is a credit/debit card and a smartphone to unlock and book the bike closer to you. Would you buy or rent the bike?

(1) I would be satisfied with my decision to rent (buy) the bike; 
(2) The choice to rent (buy) the bike would be a wise one;

(3) I think that I did the right thing when I decided to rent (buy) the bike;

(4) I feel good about my decision to rent (buy) the bike.

\section{References}

1. Bauman, Z. Consuming Life; Polity Press: Oxford, UK, 2007.

2. Bauman, Z. Liquid modernity revisited. Die Zwischengesellschaft. Aufbrüche Zwischen Tradit. Und Mod. 2016, 10, 11-22.

3. Bardhi, F.; Eckhardt, G.M. Access-based consumption: The case of car sharing. J. Consum. Res. 2012, 39, 881-898. [CrossRef]

4. Bardhi, F.; Eckhardt, G.M. Liquid consumption. J. Consum. Res. 2017, 44, 582-597. [CrossRef]

5. Organization for Economic Co-operation and Development. Gross Domestic Product (GDP). Available online: https:/ / data.oecd. org/gdp/gross-domestic-product-gdp.htm (accessed on 14 October 2021).

6. Grishin, V.I.; Ustyuzhanina, E.V.; Komarova, I.P. Main problems with calculating GDP as an indicator of economic health of the country. Int. J. Civil. Eng. Technol. 2019, 10, 1696-1703.

7. Brooking Institution. GDP as a Measure of Economic Well-Being. Available online: https://www.brookings.edu/research/gdpas-a-measure-of-economic-well-being (accessed on 14 October 2021).

8. Schmitt, B. Inflation, Unemployment and Capital Malformations; Routledge: London, UK; New York, NY, USA, $2021 ;$ p. 33.

9. Cencini, A. Elementi Di Macroeconomia Monetaria; CEDAM: Padova, Italy, 2008; pp. 34-35.

10. The World Bank. Final Consumption Expenditure (\% of GDP)—United Kingdom. Available online: https://data.worldbank.org/ indicator $/$ NE.CON.TOTL.ZS?locations=GB (accessed on 14 October 2021).

11. The World Bank. Final Consumption Expenditure (\% of GDP). Available online: https://data.worldbank.org/indicator/NE. CON.TOTL.ZS (accessed on 14 October 2021).

12. VoxEU.org. Household Debt and Spending in the UK. Available online: https://voxeu.org/article/household-debt-andspending-uk (accessed on 14 October 2021).

13. Manison, L.G.; Savvides, S.C. Neglect private debt at the economy's peril applying balance sheet recession analysis to the post bail-in Cyprus economy. Camb. Resour. Int. Inc. Dev. Discuss. Pap. 2007, 6, 1-13.

14. Sakao, T.; Sandström, G.Ö.; Matzen, D. Framing research for service orientation of manufacturers through PSS approaches. J. Manuf. Technol. Manag. 2009, 20, 754-778. [CrossRef]

15. Haber, N.; Fargnoli, M. Sustainable product-service systems customization: A case study research in the medical equipment sector. Sustainability 2021, 13, 6624. [CrossRef]

16. Lombardi, M.; Mohanti, M.; Shim, I. The real effects of household debt in the short and long run. BIS Work. Pap. 2017, 607, 1-40.

17. Jemielniak, D.; Przegalinska, A. Collaborative Society; The MIT Press: Cambridge, MA, USA; London, UK, 2020 ; p. 6.

18. Minami, A.; Ramos, C.; Bruscato Bortoluzzo, A. Sharing economy versus collaborative consumption: What drives consumers in the new forms of exchange? J. Bus. Res. 2021, 128, 124-137. [CrossRef]

19. Geisinger, A.; Laurell, C.; Öberg, C.; Sandström, C. How sustainable is the sharing economy? On the sustainability connotations of sharing economy platforms. J. Clean. Prod. 2019, 206, 419-429. [CrossRef]

20. Angelovska, J. The influence of demographics, attitudinal and behavioural characteristics on motives to participate in the sharing economy and expected benefits of participation. In Becoming a Platform in Europe: On the Governance of the Collaborative Economy; Teli, M., Bassetti, C., Eds.; Now Publishers Inc.: Boston, MA, USA; Delft, The Netherlands, 2021; pp. 35-58.

21. Karginova-Gubinova, V.; Volkov, A.; Tishkov, S.; Shcherbak, A. The impact of economic interests on eco-consumption: The case of the Russian Arctic Zone of Karelia. Entrep. Sustain. Issues 2021, 8, 68-84. [CrossRef]

22. Eurostat. Individuals-Use of Collaborative Economy (Until 2019). Available online: https://appsso.eurostat.ec.europa. $\mathrm{eu} /$ nui/show.do?query=BOOKMARK_DS-887800_QID_-F1F1D92_UID_-3F171EB0\&layout=INDIC_IS,L,X,0;GEO,L,Y,0; IND_TYPE,L,Z,0;TIME,C,Z,1;UNIT,L,Z,2;INDICATORS,C,Z,3;\&zSelection=DS-887800IND_TYPE,IND_TOTAL;DS-8878 00INDICATORS,OBS_FLAG;DS-887800UNIT,PC_IND;DS-887800TIME,2019;\&rankName1=UNIT_1_2_-1_2\&rankName2 =INDICATORS_1_2_-1_2\&rankName3=IND-TYPE_1_2_-1_2\&rankName4=TIME_1_0_0_0\&rankName5=INDIC-IS_1_2_0_0\& rankName6=GEO_1_2_0_1\&rStp=\&cStp=\&rDCh=\&cDCh=\&rDM=true\&cDM=true\&footnes=false\&empty=false \&wai=false\& time_mode=ROLLING\&time_most_recent=false\&lang=EN\&cfo=\%23\%23\%23\%2C $\% 23 \% 23 \% 23 . \% 23 \% 23 \% 23$ (accessed on 14 October 2021).

23. Eurostat. Gross Debt-to-Income Ratio of Households. Available online: https://ec.europa.eu/eurostat/databrowser/view/tec0 0104/default/table?lang=en (accessed on 14 October 2021).

24. Eurostat. HICP—Annual Data (Average Index and Rate of Change). Available online: http://appsso.eurostat.ec.europa.eu/nui/ show.do?lang=en\&dataset=prc_hicp_aind (accessed on 14 October 2021).

25. Centre for European Policy Studies (CEPS). EUROPE's COLLABORATIVE ECONOMY—Charting a Constructive Path Forward. Available online: https:/ / www.ceps.eu/ceps-events/europes-collaborative-economy-charting-a-constructive-path-forward (accessed on 14 October 2021).

26. Munkøe, M.M. Regulating the European sharing economy: State of play and challenges. Intereconomics Rev. Eur. Econ. Policy 2017, 52, 38-44. [CrossRef] 
27. The World Bank. Individuals Using the Internet (\% of Population)—United States. Available online: https://data.worldbank. org/indicator/IT.NET.USER.ZS?locations=US (accessed on 14 October 2021).

28. The World Bank. Individuals Using the Internet (\% of Population)_European Union. Available online: https://data.worldbank. org/indicator/IT.NET.USER.ZS?locations=EU (accessed on 14 October 2021).

29. Bock, A.K.; Bontoux, X.; Figueiredo do Nascimento, S.; Szczepanikova, A. The Future of the EU Collaborative Economy. Using Scenarios to Explore Future Implications for Employment; Publications Office of the European Union: Luxembourg, 2016; p. iii.

30. Laužikas, M.; Miliūtè, A. Liaisons between culture and innovation: Comparative analysis of South Korean and Lithuanian IT companies. Insights Into Reg. Dev. 2020, 2, 523-537. [CrossRef]

31. Petropoulos, G. An economic review of the collaborative economy. Bruegel Policy Contrib. 2017, 5, 1-17.

32. PricewaterhouseCoopers. Sharing or Paring? Growth of the Sharing Economy; PricewaterhouseCoopers: Budapest, Hungary, 2015; p. 7.

33. Vaughan, R.; Daverio, R. Assessing the Size and Presence of the Collaborative Economy in Europe; European Commission: Brussels, Belgium, 2016; p. 15.

34. Yaraghi, M.; Ravi, S. The current and future state of the sharing economy. Brook. India IMPACT 2017, 032017, 1-34. [CrossRef]

35. World Bank Blogs. Who Shares in the European Sharing Economy? Available online: https://blogs.worldbank.org/digitaldevelopment/who-shares-european-sharing-economy (accessed on 14 October 2021).

36. Turón, K. Social barriers and transportation social exclusion issues in creating sustainable car-sharing systems. Entrep. Sustain. Issues 2021, 9, 10-22.

37. UK Parliament-House of Commons Library. Components of GDP: Key Economic Indicators. Available online: https:// commonslibrary.parliament.uk/research-briefings/sn02787/ (accessed on 14 October 2021).

38. German Federal Ministry for Economic Affairs and Energy. Regulatory Environment and Incentives for Using Electric Vehicles and Developing a Charging Infrastructure. Available online: https://www.bmwi.de/Redaktion/EN/Artikel/Industry/regulatoryenvironment-and-incentives-for-using-electric-vehicles.html (accessed on 14 October 2021).

39. Batool, M.; Ghulam, H.; Hayat, M.A.; Naeem, M.Z.; Ejaz, A.; Imran, Z.A.; Spulbar, C.; Birau, R.; Gorun, T.H. How COVID-19 has shaken the sharing economy? An analysis using Google trends data. Econ. Res.-Ekon. Istraživanja 2020, 34, 2374-2386. [CrossRef]

40. Buheji, M. Sharing economy and communities attitudes after COVID-19 pandemic-Review of possible socio-economic opportunities. Am. J. Econ. 2020, 10, 395-406. [CrossRef]

41. Hossain, M. The effect of the Covid-19 on sharing economy activities. J. Clean. Prod. 2021, 280, 124782. [CrossRef]

42. Vinod, P.P.; Sharma, D. COVID-19 impact on the sharing economy post-pandemic. Australas. Account. Bus. Financ. J. 2021, 15, 37-50. [CrossRef]

43. Demsetz, H. The structure of ownership and the theory of the firm. J. Law Econ. 1983, 26, 375-390. [CrossRef]

44. Belk, R. Third world consumer culture. In Marketing and Development: Towards Broader Dimensions; Kumku, E., Firat, A.F., Eds.; JAI Press: Greenwich, CT, USA, 1988; pp. 103-127.

45. Berry, L.L.; Maricle, K.E. Consumption without ownership: Marketing opportunity for today and tomorrow. MSU Bus. Top. 1973, 21, 33-41.

46. Lyaskovskaya, E.; Khudyakova, T. Sharing economy: For or against sustainable development. Sustainability 2021, $13,11056$. [CrossRef]

47. Belk, R. Why not share rather than own? Ann. Am. Acad. Political Soc. Sci. 2007, 611, 126-140. [CrossRef]

48. Leung, E.W.L.; Cito, M.C.; Paolacci, G.; Puntoni, S. Preference for material products in identity-based consumption. Mark. Sci. Inst. Work. Pap. Ser. 2020, 20, 1-22. [CrossRef]

49. Fournier, S.; Lee, L. Getting brand communities right. Harv. Bus. Rev. 2009, 87, 105-111.

50. Catulli, M.; Lindley, J.; Reed, N.; Green, A. What is mine is not yours: Further insight on what access-based consumption says about consumers. Res. Consum. Behav. 2013, 15, 185-208.

51. Schmidt, D.M.; Bauer, P.; Mörtl, M. Product-service systems for influencing customer barriers and customer acceptance. J. Econ. Bus. Manag. 2015, 3, 990-993. [CrossRef]

52. Lawson, S.J.; Gleim, M.R.; Perren, R.; Hwang, J. Freedom from ownership: An exploration of access-based consumption. J. Bus. Res. 2016, 69, 2615-2623. [CrossRef]

53. Edbring, E.G.; Lehner, M.; Mont, O. Exploring consumer attitudes to alternative models of consumption: Motivations and barriers. J. Clean. Prod. 2016, 123, 5-15. [CrossRef]

54. Guttentag, D.; Smith, S.; Potwarka, L. Why tourists choose Airbnb: A motivation-based segmentation study. J. Travel Res. 2017, 57, 342-359. [CrossRef]

55. Hellwig, K.; Morhart, F.; Girardin, F.; Hauser, M. Exploring different types of sharing: A proposed segmentation of the market for "sharing" businesses. Psychol. Mark. 2015, 32, 891-906. [CrossRef]

56. Tussyadiah, I.P.; Zach, F. Identifying salient attributes of peer-to-peer accommodation experience. J. Travel Tour. Mark. 2017, 34, 636-652. [CrossRef]

57. Nielsen. Sustainable shoppers. Buy the Change They Wish to See in the World. Available online: https://www.nielsen.com/wpcontent/uploads/sites/3/2019/04/global-sustainable-shoppers-report-2018.pdf (accessed on 25 November 2021).

58. Gleim, M.; Lawson, S. Spanning the gap: An examination of the factors leading to the green gap. J. Consum. Mark. 2014, 31, 503-514. [CrossRef] 
59. Hartmann, P.; Apaolaza-Ibáñez, V. Consumer attitude and purchase intention toward green energy brands: The roles of psychological benefits and environmental concern. J. Bus. Res. 2012, 65, 1254-1263. [CrossRef]

60. Exploring car sharing usage motives: A hierarchical means-end chain analysis. Transp. Res. Part A: Policy Pract. $2013,47,69-77$.

61. Hartl, B.; Sabitzer, T.; Hofmann, E.; Penz, E. "Sustainability is a nice bonus" the role of sustainability in carsharing from a consumer perspective. J. Clean. Prod. 2018, 202, 88-100. [CrossRef]

62. Prieto, M.; Stan, V.; Baltas, G. New insights in peer-to-peer carsharing and ridesharing participation intentions: Evidence from the "provider-user" perspective. J. Retail. Consum. Serv. 2022, 64, 102795. [CrossRef]

63. Schwarz, N.; Clore, G.L. Mood, misattribution, and judgments of well-being: Informative and directive functions of affective states. J. Personal. Soc. Psychol. 1983, 45, 513-523. [CrossRef]

64. Wright, W.F.; Bower, G.H. Mood effects on subjective probability assessment. Organ. Behav. Hum. Decis. Process. 1992, 52, $276-291$. [CrossRef]

65. Forgas, J.P.; Ciarrochi, J. On being happy and possessive: The interactive effects of mood and personality on consumer judgments. Psychol. Mark. 2001, 18, 239-260. [CrossRef]

66. Isen, A.M.; Means, B. The influence of positive affect on decision-making strategy. Soc. Cogn. 1983, 2, 18-31. [CrossRef]

67. Haws, K.L.; Winterich, K.P.; Naylor, R.W. Seeing the world through GREEN-tinted glasses: Green consumption values and responses to environmentally friendly products. J. Consum. Psychol. 2014, 24, 336-354. [CrossRef]

68. Steenkamp, J.-B.E.M.; Maydeu-Olivares, A. Stability and change in consumer traits: Evidence from a 12-year longitudinal study, 2002-2013. J. Mark. Res. 2015, 52, 287-308. [CrossRef]

69. Muniz, A.M.; O'Guinn, T.C. Brand community. J. Consum. Res. 2001, 27, 412-432. [CrossRef]

70. Lastovicka, J.L.; Bettencourt, L.A.; Hughner, R.S.; Kuntze, R.J. Lifestyle of the tight and frugal: Theory and measurement. J. Consum. Res. 1999, 26, 85-98. [CrossRef]

71. Sharma, P. Measuring personal cultural orientations: Scale development and validation. J. Acad. Mark. Sci. 2010, 38, 787-806. [CrossRef]

72. Hofstede, G.H. Culture's Consequences: Comparing Values, Behaviors, Institutions and Organizations Across Nations, 2nd ed.; Sage Publications: Thousand Oaks, CA, USA; London, UK; New Delhi, India, 2001.

73. Pick, D.; Thomas, J.; Tillmanns, S.; Krafft, M. Customer win-back: The role of attributions and perceptions in customer's willingness to return. J. Acad. Mark. Sci. 2016, 44, 218-240. [CrossRef]

74. Kahn, B.E. Consumer variety-seeking among goods and services: An integrative review. J. Retail. Consum. Serv. 1995, 2, 139-148. [CrossRef]

75. Campbell, A. Subjective measures of well-being. Am. Psychol. 1976, 31, 117-124. [CrossRef]

76. Roberts, B.W.; Luo, J.; Briley, D.A.; Chow, P.I.; Su, R.; Hill, P.L. A systematic review of personality trait change through intervention. Psychol. Bull. 2017, 143, 117-141. [CrossRef] [PubMed]

77. Punj, G.; Stewart, D.W. Cluster analysis in marketing research: Review and suggestions for application. J. Mark. Res. 1983, 20, 134-148. [CrossRef]

78. MacQueen, J. Some methods for classification and analysis of multivariate observations. In Berkeley Symposium on Mathematical Statistics and Probability, Location of Conference, Country, Date of Conference; Le Cam, L.M., Neyman, J., Eds.; The Regents of the University of California: Oakland, CA, USA, 1967; pp. 281-297.

79. Oliver, R.L. A cognitive model of the antecedents and consequences of satisfaction decisions. J. Mark. Res. 1980, 17, 460-469. [CrossRef]

80. Iorio, M.; Monni, S.; Brollo, B. The Brazilian Amazon: A resource curse or renewed colonialism? Entrep. Sustain. Issues 2018, 5, 438-451. [CrossRef]

81. Fakunle, S.O.; Ajani, A.O. An empirical study of community involvement in household solid waste management: A case study. Insights Reg. Dev. 2021, 3, 114-127. [CrossRef] 